\title{
From Look East to Act East : Opportunities for North-East India with Special Reference to Silchar
}

\author{
Priyotosh Sharma \\ Research Scholar \\ Department of Political Science \\ Assam University, Silchar \\ Email: priyotoshsharma94@gmail.com
}

\begin{abstract}
The Act East Policy of India which actually succeeded India's Look East Policy has deepened India's engagement and ties with the East and Southeast Asian countries. The Act East Policy is a continuation of former Look East Policy of India which was introduced by $P$. $V$. Narasimha Rao Government in the early years of 1990s. If we, however, look at both the policies we could find the Act East Policy has reached far beyond in several areas where the former policy could not reach. The Act East Policy emphasizes on practicing more actionoriented policies towards East and Southeast Asian Countries so that India can emerge as a major power in Asia. Under the Act East Policy, India's linkages and connectivity with the Southeast Asian countries and ASEAN have been strengthened through a numbers of bilateral and regional trade agreements. The new Policy also aims at effective implementation of proposed policies and programs by developing better relations with these countries through bilateral talks, trade, business and economic, strategic and cultural ties. This paper tries to summarize the opportunities that the Act East Policy offers to India in general and to the North-East India, in particular. To point out the role Silchar and its strategic importance in the Act Policy is another objective of this paper. At the end, it highlights the major challenges which may harm the growth of Act East Policy of India.
\end{abstract}

Keywords: Act East Policy, East Asia, Southeast Asia, ASEAN, North-East India, Silchar, Opportunity

\section{Introduction}

The Look East Policy initiated by P.V Narasimha Rao Government in early 90s with an aim to promote and ensure India`s economic and strategic relations with the East and Southeast Asian nations is reshaped as Act East Policy in 2014. The Narendra Modi Government after coming to power in May, 2014, initiated the Act East Policy to further enhance and strengthen India's relations with neighboring countries and the ASEAN members. India aims at effective implementation of the policy by developing better relations with the neighboring nations through bilateral talks, trade and economic ties. The Act East Policy reflects both the continuity in Indian diplomacy over the last decade and half, and a significant measure of bipartisan consensus on the new orientation of foreign policy. A closer look would reveal that while there is continuity, there are several significant areas also where Act East Policy has gone far beyond what Look East Policy achieved in more than twenty years.

Look East Policy, initiated by P.V. Narasimha Rao Government in early years of last decade of the $20^{\text {th }}$ century, seeks to promote and ensure India's economic and strategic relations with the nations of East and South-east Asia. The policy aims at securing India's position as a regional power. Under the Act East Policy, India-Southeast Asia and India-ASEAN relations witness a new dimension. From the beginning of Look East Policy, India's engagements with the East and South-east Asian countries have shown both hope and despair. With the disintegration of erstwhile USSR and failure of India's policy in South Asia, a vacuum was 
created and India left with no other option but to look and engage with eastern neighbors. Following the situations, India formulated Look East Policy and it remained the guiding policy for India's foreign relationships for more than two decades.

India liberalized her economy in 1991 and it was followed by several other replacement in India's economic and foreign policy strategies. Following the path of liberalization, India extended its economic and trade transactions with neighboring foreign countries. In its continuation, the Look East Policy aimed to strengthen India's economic ties with the South Asian and East Asian countries. It focused on improving economic ties with the said nations. Along with economic trade and business with the countries of East and Southeast Asia, India's political and institutional linkages in the Asia Pacific region have also been deepened by this Policy. It showed some impressive gains in twenty years since its inception. India becomes a sectoral partner of ASEAN in 1992 and a dialogue partner and a member of the ASEAN Regional Forum (ARF) in 1996. India and ASEAN entered into a summit partnership, on the occasion of $10^{\text {th }}$ Anniversary of the Look East Policy, in 2002. India and ASEAN launched negotiations for a Free Trade Agreement (FTA) in goods in 2003. (Sajjanhar, 2016) However, in the past few years, the relationship could not maintain the same momentum and India realized that she should not merely 'look' towards the East, but more importantly 'act' and 'engage' with East. The Modi-led NDA Government has accorded serious attention and high priority to India's Look East Policy. Today, India is not merely looking at the East, but promising to act with the East. The Look East Policy of India has been reshaped as the Act East Policy by the Modi-led NDA Government in 2014 and Indian Prime Minister Modi at the $12^{\text {th }}$ ASEAN-India Summit and the $9^{\text {th }}$ East Asia Summit held in Nay Pyi Taw, Myanmar in November 2014, has formally enunciated the Act East Policy.

\section{Background to Look East Policy}

The Policy of looking towards East, adopted in 90 s of the $20^{\text {th }}$ century, was a reaction and correction in India's foreign policy in response to post-Cold War international scenario. During early post-Cold War years, there was a change in the laws and policies of world economic powers and there was a shift of concentration from West to the East due to evolving geopolitical powers in Asia Pacific region. India could sense and realize the fact that she should revive political ties, forge regional security cooperation and develop economic linkages with the East Asian countries by increasing integration and bondages. Hence, over the years India has institutionalized its association with the East and South East Asia. Prof. S.D Muni, in his paper titled as 'India's 'Look East Policy: The Strategic Dimension', has discussed the various waves of India's Look East Policy. (Muni, 2011) He briefly traced the background of India's Look East Policy and has shown how the policy evolved through various phases while the Policy has its roots in early times.

In the beginning of 1990s, the situation of world politics was different. India adopted its Look policy in a more different global situation. The Soviet Union was collapsed and the Cold War was just over. India was looking for new friends and had to improve its foreign relations with the foreign countries. India's relationship with neighboring countries was also not more amiable and the West Asia was under turmoil after the first Gulf War. India needed to look east to find new allies and friends especially among the Southeast Asian countries which were economically potential. Thus, India cultivated its economic and bilateral ties with the East and Southeast Asian countries and upgraded the Look East policy. (Viquaruddin, 2018) Later on, it became a responsive initiative adopted under the foreign policy of Narasimha Rao Government to strengthen and secure India's position as a regional power.

The Look East Policy has emerged as an important foreign policy initiative of India in the post-Cold-War period. In 2003, the second phase of Look East Policy was started. It extends the coverage of the Look East from Australia to East Asia and ASEAN also comes under its core focus. However, the Look East Policy was originated in a situation where the world witnessed a transformation to liberal democratic economy and flourishing of liberal 
capitalism. The globalization started flowing and the government of India had to initiate some new kind of foreign policy to explore more national interest and also to adjust with the changing situations. (Haokip, 2015)

\section{Opportunities for and Importance of North-East India}

Since the Act East is an extended version of the Look East whose scope and subject matter was limited, its matters of concern and goals are more. Unlike the Look East, the Act East Policy has more attention in the extended neighborhood in the Asia-Pacific region. The Look East Policy was basically an economic initiative. However, under its new form, it has gained political, strategic and cultural dimensions. Unlike the Look East, the Act East Policy is a multi-dimensional approach of India's foreign policy. While the Look East Policy was driven by economic interests, the Act East is driven by economic and security interests; the Look East was limited to East and Southeast Asia, but the Act East is more extended and has covered a broad area. More importantly, it underlines the current geopolitics of the region.

The establishment of institutional mechanisms for dialogue and cooperation also systematizes and expands the scope of the new policy. The Act East Policy emphasizes on importance of the North-East of India and duly recognizes it as the gateway to the East and South-East Asia. The development of North-Eastern region gets priority under Act East Policy. Currently, India is actively engaged with ASEAN. India is a dialogue partner of ASEAN and also actively engaged in regional forum such as Bay of Bengal Initiative for Multi-Sectoral Technical and Economic Cooperation (BIMSTEC), Asia Cooperation Dialogue (ACD), Mekong Ganga Cooperation (MGC) and Indian Ocean Rim Association (IORA). (Faheem, 2019) Thus, the Act East Policy has been turned into a major engine of India's regional growth. As a political strategy, it attempts to inject new life and energy into India's regional diplomacy. It emphasizes on India's closer economic and security relations with its Asian allies. It continues to prioritize political and economic ties of India with Southeast Asian countries. It appears to be a more action-oriented policy towards the Association of South East Asian Nations (ASEAN). (Singh, 2018) The Act East promotes closer political interaction with these countries. It has expanded the scope of India's Look East Policy by expanding India's economic, security, and connectivity endeavors across a wide area including Japan, South Korea, Australia and the Pacific Island states. Indeed, the Act East Policy is a more result oriented step towards building closer relationship with India's Asia pacific partners.

Because of geographical proximity of North-East India with Southeast Asia and also from demographic point of view, the North-Eastern region of India has been assumed to play an instrumental role in reducing the space and bridging the gap between mainland India and Southeast Asia. North-East India is also very much important in the Act East Policy for various reasons. The states of North-East India have been made integral part of the growth process and current initiatives under the Act East Policy which duly recognizes the importance of North-East India as a gateway to the South East Asia. There is an opportunity to modernize and strengthen the border trade points between India, Myanmar, Bhutan, Bangladesh, Nepal and these can be connected into international trade hubs. While a large numbers of people argue that transition from the Look East to Act East Policy merely represent a change in nomenclature, but a close look and analysis reveal that that are both continuity and changes from the former policy. There are several significant areas where the Act East Policy has gone far beyond what the Look East has achieved in more than twenty years. Under rapidly changing geopolitical situations where China has emerged as one of the most important global forces, the Act East Policy is playing a significant role in India-Southeast Asia relations. The growing intimacy between India and Southeast Asia has been reflected in visit to ASEAN countries by India's top leadership such as President, Vice-President and Prime Minister over the last few years.

The Act East Policy has opened new vistas for partnership in the Asia-Pacific Region for India and the North-East of India would be benefitted through these new developments. In the 
recent years, India is trying to adopt a more pragmatic approach and has shown her wisdom and wished to be integrated with the global market. India is focusing towards Southeast Asia as the focal point for economic interaction. The experience gained under the Look East Policy during 1990s and in the first decade of present century will help India to successfully promote its Act East Policy. Under the new policy, India has the potentiality to promote its cooperation and integration with Southeast Asia and East Asian countries. The East Asian economies also took note of India's rising initiative and imperative. They may extent hands for trade and investment relations. Within the framework of Act East Policy, India focuses to promote connectivity links with the other ASEAN member countries through Myanmar and Thailand. India's engagement with ASEAN becomes multi-dimensional in recent years. In addition to economic ties, security, strategic, political, counter-terrorism and defense collaboration can be intensified through the new policy.

Cooperation to curb terrorism has assumed priority under the Act East Policy. India's defense and strategic partnerships with several of the Southeast Asian countries have been advanced. India also concludes talks on Regional Comprehensive Economic Partnership (RCEP) Agreement. The implementation of the Free Trade agreement on Investment and Services between ASEAN and India will ensure mutual cooperation and development of all the stakeholders as well as of the regions. In the connectivity sector, visible development has been made under India's new policy. Road links and other connectivity links have been established. Both ASEAN and India are aiming at people to people contact in India-Southeast Asia region. BCIM, BIMSTEC, Trilateral Highway Project, Kaladhan Multi Model Project, Mekong Ganga Cooperation etc. are landmark initiatives in this regard. India and ASEAN are cooperating in the field of Science and Technology also. So, all these programs and areas may turn into key regional economic zones of tomorrow. India in general and the North-East India in particular, will have an opportunity to derive benefit from such initiatives and programs.

Act East Policy has also sought to expand its geographical coverage beyond ASEAN partners and include other countries like Japan, Australia, Pacific Island nations, South Korea and Mongolia. India's partnership with Japan has witnessed the most dynamic growth in recent years. Several historic decisions have been made. India and Japan signed a civilian nuclear deal relating to construction of a high speed railway and Delhi-Mumbai Industrial Corridor. Both the countries are joint participator in the Malabar exercises and defense cooperation.

\section{Strategic Importance of Silchar in Act East Policy}

Silchar, situated on the South Bank of river Barak, is district headquarter of Cachar District of Assam. Being headquarter, it occupies the central point of the Barak Valley region. Northeastern states like Tripura, Mizoram, Manipur, Meghalaya and foreign country Bangladesh are very close to Silchar. Silchar possesses direct road connectivity with Tripura, Mizoram, Manipur and Meghalaya. It also serves as the door link of Tripura and Mizoram. Being an important centre, Silchar lies on two major multinational corridors- BCIM Corridor between Kolkata and Kunning and the Kaladan Multimodel Transport Network. The development of both of the road networks are integral part of India's Act East Policy. Moreover, Silchar is situated on the eastern end of India's East-West Highway Corridor and lies on the Lakhipur-Bhanga National Waterway (NW-6). Silchar, thus, is a very important junction of this whole region and also an important centre for India's Act East Policy. It is an important connecting town which connects major parts and divisions of North-East India.

Silchar is a major commercial centre and it acts as the gateway to Tripura, Mizoram and Manipur. It is a very attractive staging point for India's connection with Myanmar and ASEAN countries via Mizoram and Manipur. So, Silchar can play a vital role in India's Act East Policy and derive benefit for itself. Silchar is also being linked with proposed ImpholMandalay bus service. It is another recent development which can benefit North-Eastern region. In connection with the proposed bus service, a field survey has been done by a joint Indo-Myanmar team. It is a part of the proposed India-Myanmar-Thailand Trilateral Highway. 
Tripura is using Ashuganj River Port on Meghna for importing food and other goods. Meghna in the downstream is linked with Barak in Bangladesh. It provides an opportunity to connect Ashuganj port to National Waterwsay-6. Lakhipur (nearby Silchar) at the Assam-Manipur border can be linked with Bay of Bengal through Bangladesh. By expanding more road crossings along with the borders of Nagaland and Myanmar, Arunachal Pradesh and Myanmar, the region can be link to the Stillwell Road (Ledo Road) to bring in supplies to the geographically contiguous areas along India and Myanmar.

The above discussions show that North-East India can have opportunities to flourish bilateral, strategic, economic and other partnerships with the East and Southeast Asian countries under the Act East Policy. In recent years, India has been engaged in formulating short-term, medium-term and long-term policies with these countries. If utilized, these opportunities may help India in realizing her goals and achieving the objectives which will ensure development of North-East India.

\section{Challenges of Act East}

India's growing engagement with East and Southeast Asian countries is, however, not free from challenges. The increase role of China in these regions has been affecting India's relationship with the region. China has expressed her dissatisfaction over the India's defense cooperation in South China Sea regions. Development of different Chinese policies, like String of Pearls, China-Pakistan Economic Corridor etc. actually encircled India and offers a threat to India's foreign engagement. China's growing influence over the East Asian countries is also a challenge for India's policies. Inequalities in regard to level of development among the ASEAN countries also affect economic relations among the regions. India also witnesses trade deficit in trade and business with the ASEAN countries and the imbalanced trade between the regions has affected India negatively.

Human trafficking and business of drugs have become an issue of concern in North-East India. It is observed that human trafficking from North-Eastern states of India and supplies of drugs from others parts of Southeast Asia to North-Eastern states constitute a major challenge of security in North-East India. Human trafficking in North-East India involves illegal traffic of child, young girls and women. People belonging to unprivileged sections of the society fall prey to wicked people involved in these kinds of activities. Growing communication links between the regions is also responsible and pave the way for these kinds of unwanted development. Bureaucratic hurdles in administrative part also disturb the gradual developments of many programs and policies in the North-Eastern region. Provisions like Inner Line Permit and existence of draconian laws like AFSPA also put a challenge to growing India's engagement with the neighboring Southeastern countries.

\section{Conclusion}

In the era of globalization, regional cooperation and regional integration lead to regional development and the involved countries always benefitted from this involvement. India's Act East Policy has provided a platform for India to derive benefit from the regional engagement and to evolve as a regional power. It enhances India's trade and investment to strengthen its relations in the East and South Asian countries. India through this Policy puts a strong road for enhanced regional connectivity. This Policy can play a vital role in developing a regional economic, strategic and cultural platform for India to fulfill its aims and maintaining healthy relations with the countries. In the coming years, India must continue to focus on further strengthening ties and collaboration with ASEAN nations and others. Partners must work to promote economic revival, seek strategic cooperation to fight terrorism, and enhance maritime security and defense cooperation. Along with, Modi's use of soft server such as Buddhism, terrorism, people to people contacts and cultural ties with the region must be continued to get the fruits from the Act East. The Government and the official should pay more care to important geopolitical hubs in North-East India like Silchar to achieve their core objectives under Act East Policy. The Government and the official should pay more care to important 
geopolitical hubs in North-East India like Silchar to achieve their core objectives under Act East Policy.

\section{REFERENCES}

[1] Chandra, P (2006) International Relations: Foreign Policies of Major Powers and Regional Systems, New Delhi, Vikas Publishers

[2] Chopra, V. D. (2006). India's Foreign Policy In The $21^{\text {st }}$ Century, New Delhi, Kalpaz Publication

Dutt, V.P. (2007) India's Foreign Policy Since Independence, New Delhi, National Book Trust

[3] Faheem, M (February, 2019). Strengthening India's Act Policy through sub-Regional Organisation BIMSTEC: New Regional Cooperation Approach, ResearchGate

[4] Ganguly, S (2010). India's Foreign Policy: Retrospect and Prospect, New Delhi, Oxford India Press

[5] Haokip, T (2015) India's Look East Policy: Its Evolution and Approach, Sage Journals

[6] Mukhim, P (October, 2018). Between Look East And Act East Is A Swinging Bridges That Divides. Retrieved from https://www.outlookindia.com/magazine/story/between-look-east-and-act-east-is-a-swinging-bridges-thatdivedes/300831

[7] Muni, S.D. (February, 2011). India's 'Look East' Policy: The strategic dimension, ISAS Working Paper, Issue no. 121

[8] Panda, R (January, 2018). From Look East to Act East, Retrieved from https://www.dailypioneer.com/2018/columnists/from-look-east-to-act-east.html

[9] Sajjanhar, A (May, 2016). Taking Stock of India's Act East Policy, ORF Issue Brief, Issue no. 142

[10] Shubham, (May, 2018).Modi in Indonesia: From Look East to Act East, India's policy Upgrade

[11] Singh, A (April, 2018). The Nautical Dimension of India's "Act East" Policy, Policy report, Rajaratnam School of International Studies

[12] Singh, K.R. (November, 2014). Look East Policy; India's Motive and Opportunities \& Threats Ahead, Asian Journal of Research in Business Economics and Management; Vol. 4, Issue 11, pp. 165-171

[13] Singh, U.B. (December, 2018). Significance of India's Act East Policy and Engagement with ASEAN, Institute for Defence Studies and Analysis

[14] Surjitkumar, N (February, 2016). India's Act East Policy: Problems and Prospects for North-East India

[15] Viquaruddin, M (August, 2018). Changing Dimensions of India's Foreign Policy, Journal of Political Science and Public Affairs; Vol. 6, Issue 3

[16] Viswanath, A (February, 2018). Why Act East will work when Look East did not. Retrieved from https://www.financialexpress.com/opinion/why-act-east-will-work-when-look-east-did-not/1048663 